\title{
From rabbit antibody repertoires to rabbit monoclonal antibodies
}

\author{
Justus Weber, Haiyong Peng and Christoph Rader \\ In this review, we explain why and how rabbit monoclonal antibodies have become outstanding reagents for laboratory research \\ and increasingly for diagnostic and therapeutic applications. Starting with the unique ontogeny of rabbit B cells that affords \\ highly distinctive antibody repertoires rich in in vivo pruned binders of high diversity, affinity and specificity, we describe the \\ generation of rabbit monoclonal antibodies by hybridoma technology, phage display and alternative methods, along with an \\ account of successful humanization strategies.
}

Experimental \& Molecular Medicine (2017) 49, e305; doi:10.1038/emm.2017.23; published online 24 March 2017

\section{INTRODUCTION}

European rabbits (Oryctolagus cuniculus; Figure 1) have played an important role as animal models in immunology for many decades. ${ }^{1,2}$ Today, rabbits are still a major source for a wide variety of monoclonal antibodies (mAbs) and polyclonal antibodies (pAbs) with broad utility. pAbs can be described as a set of different antibodies generated in response to a specific pathogen or antigen, generally targeting different epitopes. mAbs, on the other hand, contain a defined antigen-binding site (paratope) that typically binds with high affinity and specificity to only one epitope. From a pharmaceutical point of view, mAbs provide a molecularly defined and reproducible product, whereas pAbs are traditionally an imprecise mixture of different antibodies. ${ }^{3}$ As is the case for mouse and human mAbs, IgG is the most common isotype of rabbit mAbs (Figure 2).

Rabbit pAbs have been used extensively as analytical tools in biomedical research and especially for immunological techniques, such as immunohistochemistry (IHC), western blotting and flow cytometry. Rabbit pAbs have also been utilized as an important tool for food safety assessments. ${ }^{4}$ In addition, rabbit pAbs have been used in a clinical context. A prominent example is anti-thymocyte globulin (ATG). ATG is a mixture of purified polyclonal rabbit, horse or goat IgGs against human $\mathrm{T}$ cells that has been used as an immunosuppressive drug for decades. In organ and allogeneic bone marrow transplantation, ATG application causes rapid depletion of $\mathrm{T}$ cells, leading to a decreased risk for rejection and acute graft-versus-host disease. However, ATG does not induce long-term tolerance. ${ }^{5}$
Rabbit ATG is one of the most commonly used ATGs, due to its higher lymphocytotoxicity compared to horse ATG. ${ }^{6}$ Rabbit ATG known as Thymoglobulin (Sanofi Genzyme, Inc., Cambridge, MA, USA) was approved by the US Food and Drug Administration (FDA) in 1998. More recently, an improved rabbit pAbs cocktail targeting human leukocytes was reported as a potential immunosuppressive drug in xenogeneic (for example, pig to human) organ transplantation. ${ }^{7}$ In addition, one rabbit pAb is currently approved by the FDA as an in vitro diagnostic tool (c-Kit pharmDx; Agilent Technologies, Inc., Santa Clara, CA, USA) for the IHC-based detection of CD117 (c-kit) expression in gastrointestinal stromal tumors to aid treatment decisions. ${ }^{8}$

mAbs and mAb-derived antibody therapeutics ${ }^{9,10}$ are currently widely used to treat human diseases, such as cancer and autoimmune diseases. ${ }^{11,12}$ Although no therapeutic rabbit mAbs have been approved by the FDA thus far, 11 rabbit mAbs are FDA-approved in vitro diagnostic tools in the clinic. ${ }^{13,14}$ Ten of these mAbs are being used to detect the expression of tumor-associated antigens, including HER2, estrogen receptors, progesterone receptors and $\mathrm{PD}-\mathrm{L} 1$. One $\mathrm{mAb}$ is used to detect helicobacter pylori infections. A rabbit $\mathrm{mAb}$ to human androgen receptor splice variant 7 has emerged as a promising tool for the detection of circulating tumor cells by immunofluorescence and IHC in prostate cancer. ${ }^{15,16}$ In addition, several rabbit mAb-derived therapeutics are currently being investigated in clinical trials registered at ClinicalTrials. gov. In oncology, examples include sevacizumab (Simcere Pharmaceutical Group, Inc., Nanjing, China), a humanized 


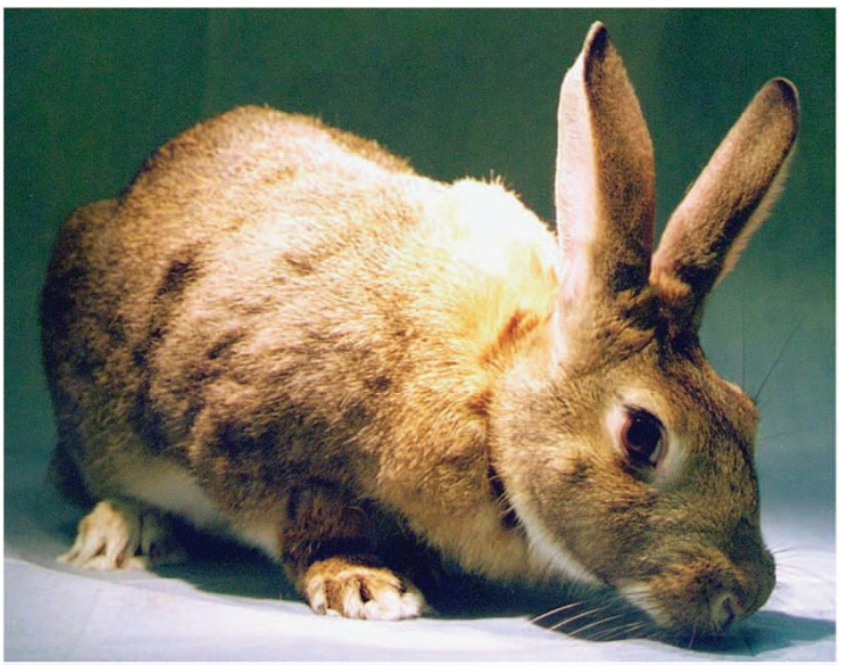

Figure 1 Oryctolagus cuniculus. Shown is an individual with b9 $\kappa$-light-chain allotype from a pedigreed non-inbred colony of rabbits developed and characterized at the US National Institute of Allergy and Infectious Diseases, National Institutes of Health. The rabbits are currently housed at a rabbitry in Stanwood, WA, USA, owned by $R$ \& R Research, Inc. and available for custom immunization and harvests of peripheral blood, spleen and bone marrow. (Photo courtesy of Dr Rose G. Mage).

rabbit anti-human vascular endothelial growth factor $\mathrm{mAb}$ (NCT02453464), ${ }^{17,18}$ APX005M (Apexigen, Inc., San Carlos, CA, USA), a humanized rabbit anti-human CD40 mAb (NCT02482168), and YYB101, a humanized rabbit antihuman HGF mAb (YooYoung Pharmaceutical Co., Inc., Seoul, Korea; NCT02499224). ${ }^{19,20}$ Further, chimeric antigen receptor $\mathrm{T}$ cells based on a rabbit anti-human ROR $1 \mathrm{mAb}^{21}$ have commenced clinical trials recently (NCT02706392). ${ }^{22,23}$ In ophthalmology, humanized rabbit anti-vascular endothelial growth factor mAb brolucizumab (Alcon, Inc., Hünenberg, Switzerland), a mAb in $\mathrm{scFv}$ format administered intravitreally, is being investigated in advanced clinical trials (NCT02307682 and NCT02434328). ${ }^{24}$ Following these examples, a number of rabbit $\mathrm{mAb}$-derived therapeutics are expected to transition from preclinical to clinical studies in the near future. Currently, only a handful of companies develop rabbit or rabbit-derived mAbs for laboratory research and for diagnostic and therapeutic applications. Some of the companies in the global market are Abcam, Inc. (Cambridge, UK; RabMAb platform; through acquisition of Epitomics, Inc., Burlingame, CA, USA, in 2012); Alcon, Inc. (through acquisition of ESBAtech, Inc., Schlieren, Switzerland in 2009); Apexigen, Inc. (San Carlos, CA, USA; spun out by Epitomics, Inc. in 2010); Cell Signaling Technology, Inc. (Danvers, MA, USA; currently listing $>4000$ different rabbit mAbs); Agilent Technologies, Inc.; MAB Discovery, Inc., Neuried, Germany; Lab Vision Corporation, Inc., Fremont, CA, USA; Thermo Fisher Scientific, Inc. (Carlsbad, CA, USA; Invitrogen ABfinity recombinant rabbit antibodies); and Ventana Medical Systems, Inc. (Tucson, AZ, USA).

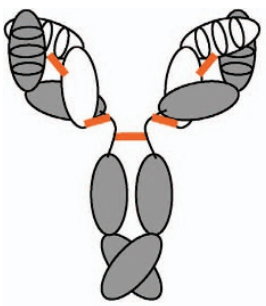

IgG-K (K1)

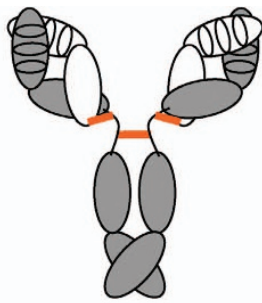

$\lg$-k (K2)

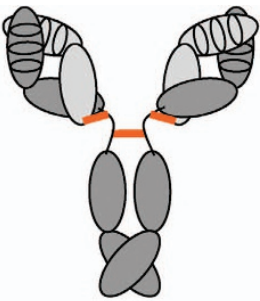

IgG- $\lambda$
Figure 2 Schematic drawing of natural rabbit antibodies in IgG format. The $\sim 150-k D a$ rabbit IgG molecule contains two identical $\kappa$ (white) or $\lambda$ (light gray) light chains paired with two identical heavy chains (dark gray). The light chain consists of an $\mathrm{N}$-terminal variable domain (VL), shown with its three CDRs, followed by one constant domain (CL). The heavy chain consists of an N-terminal variable domain $(\mathrm{VH})$, also shown with its three CDRs, followed by three constant domains $(\mathrm{CH} 1, \mathrm{CH} 2$ and $\mathrm{CH} 3) . \mathrm{CH} 1$ and $\mathrm{CH}_{2}$ are linked through a flexible hinge region that has the amino-acid sequence APSTCSKPTCP (or APSTCSKPMCP in an allotypic variant) and anchors three disulfide bridges (orange) of the IgG molecule, one for each of the two light- and heavy-chain pairs, and one for the heavy-chain pair. Notably, rabbits have two $\kappa$ light chains, K1 and K2. The more frequent $\kappa$ light chain, K1, contains an additional disulfide bridge that links $\mathrm{VL}$ and $\mathrm{CL}$. Rabbits of the commonly used New Zealand White strain have

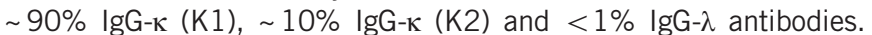
$\mathrm{CDR}$, complementarity-determining region.

What is the attraction of rabbit antibodies for the applications discussed above? Rabbits have been used to investigate immunological questions and to develop immunological techniques for $>100$ years. Thus, many standard procedures are established, published and validated, such as immunization and purification methods yielding high amounts of rabbit antibodies. $^{25}$ In addition to these practical considerations, rabbits are characterized by a variety of natural features that make their antibody repertoire very attractive for the discussed applications. First, rabbits belong to the order Lagomorpha, which is evolutionary distinct from the order Rodentia, to which, for example, mice and rats belong. ${ }^{26-29}$ Rabbit antibodies are able to recognize epitopes on human antigens that are not immunogenic in rodents, ${ }^{30}$ increasing the total number of targetable epitopes and facilitating the generation of antibodies that cross-react with mouse orthologs of human antigens. ${ }^{31-33}$ This is an important aspect for basic research and preclinical investigations with, for example, human tumor xenografts, where the presence or absence of on-target-offtumor toxicities of therapeutic antibodies provides important information prior to clinical translation. In general, rabbit anti-mouse reactivity is valuable in mouse models of human disease and has also been exploited in basic research, for example, on mouse stem cell antigens. ${ }^{34-36}$ Second, it has been observed that rabbits elicit strong immune responses against small molecules and haptens, which is uncommon in rodents. ${ }^{18,37-41}$ A third important aspect is the scarcity of inbred rabbit strains, while most mouse strains are inbred. ${ }^{1,42}$ It is thought that inbred strains in general elicit less diverse immune responses, which makes it more difficult to 
raise strong and diverse binders. ${ }^{18}$ Correspondingly, in many IHC studies that compared rabbit and mouse mAbs to the same human antigens, rabbit mAbs consistently revealed higher sensitivity. ${ }^{43-62}$ In a recent study, ${ }^{63} 1410$ rabbit mAbs raised against 15-amino-acid peptides representing 100 different antigens revealed a typical affinity range of $20-200 \mathrm{pm}$ (median $66 \mathrm{pm}$ ), as determined by high-throughput surface plasmon resonance. A fraction of rabbit mAbs even revealed higher affinities near the detection limit of $1 \mathrm{pm}$. However, the affinity range of 46 mouse mAbs (30-300 pM; median $72 \mathrm{pm}$ ) analyzed in parallel was not significantly different. ${ }^{63}$ More direct comparisons of rabbit and mouse mAbs to a wider variety of antigens are warranted to determine a significant difference in affinity. Fourth, most strategies to generate mAbs are based on the recovery of $\mathrm{B}$ cells from spleen, bone marrow or blood, which are present in higher quantities in rabbits than in mice due to their overall larger body size. (The average body weight of a 3 -month-old laboratory rabbit is $2.5 \mathrm{~kg}$ compared to $25 \mathrm{~g}$ for a 6-week-old laboratory mouse.) For example, 50 times more spleen B cells can be recovered from rabbits compared to mice. ${ }^{18}$ In addition, the larger blood volume of rabbits compared to mice facilitates mass spectrometry analyses of bulk serum IgG. ${ }^{64}$ Fifth, as discussed in the next section, rabbits use different mechanisms to genetically generate and diversify their primary and secondary antibody repertoires compared to humans and mice, effectively creating a complementary set of binders for the discussed applications. The recent sequencing and annotation of the rabbit genome (OryCun2.0 assembly) has provided new insights into this unique antibody repertoire. ${ }^{1,65,66}$

\section{ONTOGENY OF RABBIT B-CELL AND ANTIBODY REPERTOIRES}

The development of the rabbit B-cell repertoire significantly differs from that of other mammals. The current model proposes a three-step process (Figure 3) consisting of the neonatal B-cell repertoire generated by B lymphopoiesis in the fetal liver and omentum switching to bone marrow after birth, the primary 'pre-immune' B-cell repertoire evolving during the first 2 months after birth in gut-associated lymphoid tissue (GALT) and the secondary 'immune' B-cell repertoire generated upon B-cell activation by immunogen binding. ${ }^{2,67}$ The neonatal B-cell repertoire starts developing between the second and third week of gestation. ${ }^{68,69}$ Interestingly, B lymphopoiesis is very limited in the bone marrow of adult rabbits, ${ }^{70}$ indicating that $\mathrm{B}$ lymphopoiesis is mainly restricted to early development. However, B cells with germline antibody sequences were found in the adult spleen. ${ }^{71}$ In addition, in a rabbit-to-rabbit adoptive transfer model, it was shown that rabbit B cells were able to engraft into host stem cell niches, ${ }^{72}$ which led to the conclusion that rabbit B cells are long-lived and potentially self-renewing and may thus sustain the rabbit antibody repertoire throughout a rabbit's lifetime. ${ }^{73}$

Rabbits mainly rearrange their heavy chains first followed by their light chains ${ }^{74}$ and thus follow the primary B-cell development pathway proposed by Ehlich et al. ${ }^{75}$ In brief, this

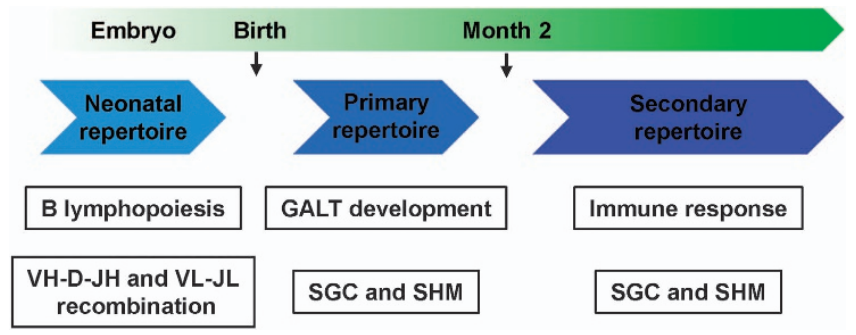

Figure 3 Ontogeny of rabbit B-cell and antibody repertoires. The three principally different developmental stages of B-cell and antibody diversification in the rabbit are shown. GALT; gut-associated lymphoid tissue; SGC, somatic gene conversion; SHM, somatic hypermutation.

model proposes the VH-D-JH recombination of the heavy chain, followed by its expression as a pre-B-cell receptor. Upon stimulation of the pre-B-cell receptor, VL-JL light-chain recombination is started. Some evidence for non-templated nucleotide-addition (also known as $\mathrm{N}$-nucleotides) has been

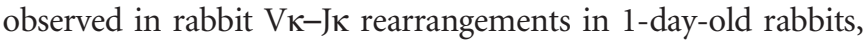
suggesting that terminal deoxynucleotidyl transferase was recently expressed. ${ }^{76}$

Although a potential pool of $200 \mathrm{VH}$ genes are present for heavy-chain rearrangement, ${ }^{66,77}$ a majority of these are infrequently or not expressed. ${ }^{78}$ There are 10-20 D genes and $4-5 \mathrm{JH}$ genes. ${ }^{79}$ However, it is known that certain genes from these clusters are preferentially utilized: $\mathrm{VH} 1$, the most D-proximal VH gene, is present in $80-90 \%$ of all heavychain gene rearrangements. ${ }^{68,79,80}$ Three different allotypes VHa1, VHa2 and $\mathrm{VHa} 3$ are known, resulting in the VHa-positive serotype. ${ }^{81,82}$ The remaining $10-20 \%$ of heavy chains contain $\mathrm{VHx}, \mathrm{VHy}$ or $\mathrm{VHz}$ genes. ${ }^{83,84}$ This finding was somewhat surprising, because there is another functional, D-proximal VH sequence significantly closer to the VH1 segment. Indeed, it could be shown that the VH4 segment is utilized in $80-90 \%$ of the heavy-chain rearrangements in VH1-negative Alicia strain rabbits. However, this heavy-chain rearrangement was very rare in adult rabbits, suggesting that the VH4 rearrangement is non-productive in most cases and thus lost in the course of development. ${ }^{69}$ Lanning et al. ${ }^{73}$ suggested negative self-antigen effects and non-efficient pairing with light chains and surrogate light chains during B-cell development as possible reasons. In addition, preferential utilization of D2a, D2b and D1 as well as JH4 could be shown. ${ }^{79}$

It is thought that rabbits compensate for this preferential utilization of certain $\mathrm{VH}, \mathrm{D}$ and $\mathrm{JH}$ genes in part by $\mathrm{N}$-nucleotide addition at the $\mathrm{VH}-\mathrm{D}$ and $\mathrm{D}-\mathrm{JH}$ junctions during recombination. ${ }^{68,69}$ Using high-throughput sequencing of antibody repertoires from three New Zealand White rabbits, Lavinder et al. ${ }^{85}$ determined that the mean \pm s.d. length of the third complementarity-determining region (CDR) of the heavy chain, which is known as HCDR3, includes both junctions, and thus is the most hypervariable of all six CDRs, is $15 \pm 4($ mode $=13)$ amino acids compared to mouse and 
human HCDR3s with mean \pm s.d. lengths of $11 \pm 2$ (mode $=10$ amino acids) and $15 \pm 4$ (mode $=15)$ amino acids, respectively. These findings confirmed that rabbit HCDR3s share more similarity with human HCDR3s than mouse HCDR3s and could be relevant for therapeutic applications. ${ }^{86}$

Although there is limited heavy-chain usage in the neonatal rabbits' B-cell repertoire, there may be compensation by usage of diverse light chains. There are two types of rabbit light chains $-\kappa$ and $\lambda$-with the $\kappa$ light chain present in two different isotypes called $\mathrm{K} 1$ and $\mathrm{K} 2 .{ }^{87}$ Four K1 $\kappa$-light-chain allotypes-b4, b5, b6 and b9-have been observed in domesticated rabbits. Notably, the constant domain sequences of these rabbit $\kappa$-light-chain allotypes have much higher aminoacid sequence diversity than human Ig allotypes with pairwise amino-acid sequence differences of up to $40 \%{ }^{88}$ This high degree of polymorphism exceeds the allotypic diversity of the three heavy-chain allotypes, a1, a2 and a3 ( 20\% amino-acid sequence differences), and even surpasses the allotypic diversity of major histocompatibility complex loci. ${ }^{1} \mathrm{~K} 1$ is by far the most abundant isotype and represents between 70 and $90 \%$ of all light chains, whereas the rest is usually a mixture of both $\mathrm{K} 2$ and $\lambda$-light chains. ${ }^{89}$ Many K1 light chains are characterized by an intrachain disulfide bridge between cysteine 80 in VK and cysteine 171 in $\mathrm{C \kappa}$ (Figure 2).$^{90}$ This additional disulfide bridge, which was discovered biochemically ${ }^{91,92}$ and later confirmed by X-ray crystallography, ${ }^{93,94}$ is not found in human or mouse light chains. It may contribute to the stability of rabbit antibodies and is one of many peculiarities of Ig evolution in vertebrates. This disulfide bridge is absent from rabbits of the K1-negative Basilea mutant strain that only expresses $\mathrm{K} 2$ and $\lambda$-light chains. Some but not all of the $\mathrm{K} 1$ light chains of rabbits homozygous for the $\mathrm{b} 9 \mathrm{\kappa}$-light-chain allotype ${ }^{86}$ have a cysteine 108 in J $\mathrm{K}$ that is thought to create an alternative intrachain disulfide bridge with cysteine 171 in Cк. ${ }^{89,90}$ These allotypes play an important role for the generation of rabbit mAbs by phage display and are discussed in more detail below. So far, $\sim 50$ functional Vк genes have been identified. ${ }^{76,95}$ Recently, using next-generation sequencing of rabbit antibody repertoires, Kodangattil et al. ${ }^{96}$ demonstrated that light-chain rearrangements are significantly more diverse than heavy-chain rearrangements in rabbits. In addition, the imprecise junction of VL and JL genes in rabbits encompasses particularly long stretches of $\mathrm{N}$-nucleotides, resulting in, on average, longer LCDR3s ( $12 \pm 2$ amino acids; mode $=12)$ compared to mouse and human $(9 \pm 1$ amino acids; mode =9; Figure 4). ${ }^{85}$ The longer rabbit LCDR3s are occasionally stabilized by disulfide bridges. ${ }^{97}$ Taken together, by generating a more diverse neonatal light-chain repertoire followed by a comparable degree of further diversification into primary and secondary light-chain repertoires, the light chain can compensate for the limited diversity of heavy-chain repertoires in rabbits. This may also explain the dominance of the rabbit light chain in general and LCDR3 in particular in several of the antibody/antigen complexes for which threedimensional structures have been determined by X-ray crystallography. ${ }^{94,97-100}$
The limited neonatal antibody repertoire is further diversified between week 4 and 8 after birth resulting in the primary antibody repertoire. ${ }^{67}$ This postnatal diversification is an unusual phenomenon and has so far only been observed in rabbits and pigs. ${ }^{101}$ The two main mechanisms are somatic gene conversion (SGC; templated) and somatic hypermutation (SHM; non-templated; Figures 3 and 4). SGC, predominantly used only in chicken and rabbit Ig gene diversification, ${ }^{102}$ leads to the replacement of large nucleic acid sequence stretches with DNA fragments from non-utilized VH genes. ${ }^{80,103,104}$ High-throughput sequencing revealed a mean \pm s.d. tract lengths of $59 \pm 36$ nucleotides. ${ }^{85}$ Thus, the non-expressible majority of $\mathrm{VH}$ genes play an important role for heavy-chain diversification. The predominance of this mechanism in rabbit (23\%) compared to human $(2.5 \%)$ and mouse $(0.1 \%)$ heavy chains, as determined by high-throughput sequencing, ${ }^{85}$ is thought to lead to decreased wastage: a substantial portion of VH-D-JH recombinations with $\mathrm{N}$-nucleotides addition have out-of-frame junctions, whereas SGC, a homologous DNA recombination event, ${ }^{105}$ tends to favor in-frame substitutions and extensions. ${ }^{89}$ In addition, SHM is observed at considerable levels during this developmental stage. ${ }^{83,106,107}$ Following rearrangement in the neonatal B-cell repertoire, rabbit lightchain genes also undergo SGC and SHM to diversify the primary B-cell repertoire (Figures 3 and 4). ${ }^{108}$ Further corroborating the importance of the light chain for generating diversity in rabbit antibody repertoires, SGC is more frequent $(32 \%)$ and has a longer mean \pm s.d. tract length $(86 \pm 48$ nucleotides) in rabbit $\mathrm{k}$-light chains compared to rabbit heavy chains. ${ }^{85}$

Interestingly, the generation of the primary repertoire is highly GALT-dependent. In short, GALT involves the uptake of pathogens from the gastrointestinal track by specialized epithelial cells known as $\mathrm{M}$ cells and the presentation of antigens to B cells leading to B-cell stimulation, diversification and proliferation. ${ }^{109}$ Surgical removal ${ }^{10}$ of GALT tissues, such as the Peyer's patches in the small intestines, the sacculus rotundus and the appendix ${ }^{111}$ resulted in severely immunodeficient rabbits. In addition, it was observed that germ-free rabbits developed abnormal GALT. ${ }^{112,113}$ Lanning et al. ${ }^{114}$ demonstrated that this directly correlated with reduced somatic $\mathrm{VH}-\mathrm{D}-\mathrm{JH}$ diversification compared to germ-exposed rabbits.

The secondary B-cell repertoire is generated upon antigendependent B-cell stimulation. Again, additional diversity is introduced by SGC and SHM in both heavy and light chains (Figures 3 and 4). ${ }^{15,116}$ These events further broaden the B-cell repertoire directed against a certain set of antigens associated with a specific pathogen. ${ }^{73}$

The discussed idiotypic and allotypic peculiarities of rabbit antibodies further extend to the isotype. Notably, rabbits only have one $\operatorname{IgG}$ isotype (one $\mathrm{C} \gamma$ gene) compared to four IgG isotypes in mice (IgG1, IgG2a, IgG2b and IgG3) and humans (IgG1, IgG2, IgG3 and IgG4). In contrast, rabbits have $13 \mathrm{C} \alpha$ genes giving rise to at least 10 functional IgA isotypes, the most diverse IgA system known, ${ }^{1,117}$ compared to just one 


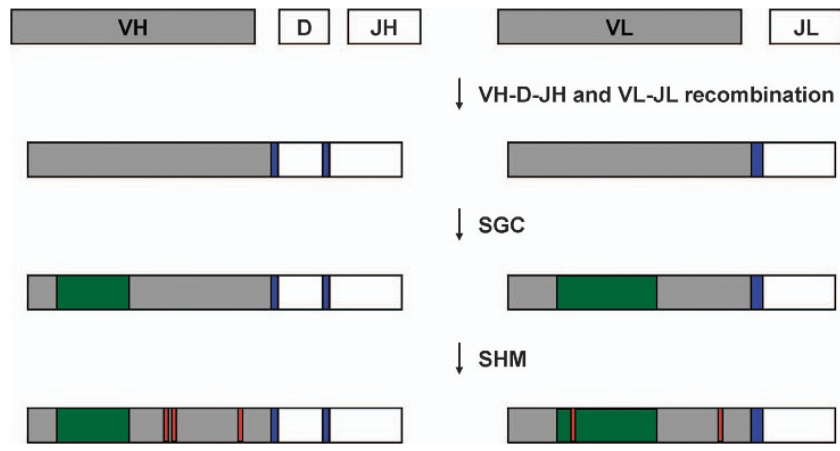

Figure 4 Molecular mechanisms of sequence diversification in rabbit antibody repertoires. Top: VH-D-JH and VL-CL recombination takes place in the neonatal B-cell repertoire. In the rabbit, $\mathrm{N}$-nucleotide additions (blue) at $\mathrm{VL}-\mathrm{CL}$ junctions (encoding LCDR3) are more extensive than those found at $\mathrm{VH}-\mathrm{D}$ and $\mathrm{D}-\mathrm{JH}$ junctions (encoding HCDR3). Middle: SGC events (green) diversify the $\mathrm{VH}$ and $\mathrm{VL}$ portion of rabbit heavy and light chains in primary and secondary B-cell repertoires and mostly localize to regions encoding HCDR1, HCDR2, LCDR1 and LCDR2. Bottom: SHM events (red) further diversify rabbit heavy and light chains in primary and secondary B-cell repertoires. SGC, somatic gene conversion; SHM, somatic hypermutation.

IgA isotype in mice and two in humans. Collectively, the unique features of B-cell ontogeny and antibody repertoire make rabbits a valuable source for the generation of antibodies of high affinity and specificity.

\section{GENERATION OF RABBIT MABS}

\section{Hybridoma technology}

The discovery and development of hybridoma technology for the generation of mAbs by Georges Köhler and César Milstein in 1975 has had a huge impact on biomedical research and its application to modern medicine. ${ }^{118,119}$ Hybridoma technology is a method to generate stable cell lines that constantly secret a defined $\mathrm{mAb}$. For this purpose, B cells derived from an immunized animal are fused with a myeloma cell line in the presence of polyethylene glycol. The hybridomas generated this way are cloned by limiting dilution, screened for favorable $\mathrm{mAb}$ characteristics and then expanded in culture to obtain high amounts of the desired mAb. ${ }^{119}$ Generally, two hybridoma types can be distinguished: first, homo-hybridomas where both host B cells and fusion cell line emerged from the same species and, second, hetero-hybridomas derived from two different species. ${ }^{120}$

Ever since their initial discovery, multiple aspects of the general technique have been modified in order to avoid certain problems related to fusion efficiency, hybridoma stability and mAb titers. ${ }^{121}$ Hybridoma technology has been used extensively to generate thousands of different $\mathrm{mAbs}$ against a wide variety of antigens. In fact, the majority of FDA-approved chimeric, humanized and human mAbs originate from hybridoma technology. ${ }^{120}$ However, all of these were derived from mouse B cells or transgenic mouse B cells with human Ig genes. Due to the favorable properties of rabbit antibodies, many groups tried to develop methods for the generation of rabbit hybridomas. This endeavor was significantly complicated by the absence of rabbit myeloma cell lines. ${ }^{122}$ Viral transformation of rabbit $\mathrm{B}$ cells to generate myeloma-like cell lines also proved to be difficult and rather inefficient. ${ }^{123}$ For these reasons, substantial efforts focused on generating rabbit-mouse hetero-hybridomas. Unfortunately, all hetero-hybridomas generated in the early days of hybridoma technology revealed poor fusion efficiency, genetic instability and impaired functional rabbit heavy- and light-chain pairings. ${ }^{124-126}$ In 1988, Raybould et al. ${ }^{122}$ generated the first stable rabbit-mouse hetero-hybridoma by polyethylene glycol-mediated fusion of rabbit spleen B cells with the mouse myeloma cell line SP2/0-Ag14. Even though they observed stable rabbit IgG expression for several months, other groups observed genetic instability and concomitant decrease of $\mathrm{mAb}$ secretion. These shortcomings could be partially addressed by extensive efforts to regularly subclone the rabbit-mouse heterohybridoma. ${ }^{127}$ The first rabbit homo-hybridoma was developed in 1995 in the laboratory of Katherine Knight. ${ }^{128}$ In order to obtain a potential rabbit fusion cell line, transgenic rabbits were generated by single-cell zygote microinjection and mated to generate $\mathrm{v}$-abl/c-myc double transgenic rabbits. This method led to the discovery of the first stable rabbit plasmacytoma cell line, 240E-1, ${ }^{129}$ which could be used as an efficient fusion partner to generate rabbit homo-hybridomas. Interestingly, Spieker-Polet et al. also showed in this publication that B cells derived from different rabbit tissues led to the generation of hybridomas secreting different ratios of IgG, IgM and IgA. However, the stability of the obtained homo-hybridomas was still a major concern and IgG secretion decreased over time. Although this decay is frequently also observed for mouse homo-hybridomas, it appeared to be more drastic in the case of rabbit homo-hybridomas. ${ }^{30,130}$ For this reason, Zhu and Pytela $^{121}$ attempted to further improve the initial $240 \mathrm{E}-1$ cell line by iterative subcloning to screen for clones with higher fusion efficiency, yielding hybridomas with higher genetic stability and more stable rabbit IgG secretion. The obtained fusion cell line 240E-W and its successors 240E-W2 and 240W3, which are characterized by higher fusion efficiency and the absence of endogenous rabbit heavy- and light-chain secretion (US Patent 7,429,487), ${ }^{41}$ are part of the proprietary RabMab platform of Epitomics, Inc. (now Abcam, Inc.) and were used to generate the therapeutic rabbit mAbs sevacizumab and APX005M discussed above.

Aside from therapeutic applications, rabbit mAbs generated by hybridoma technology have become highly valuable reagents for diagnostic applications and for laboratory research. For example, highly specific rabbit mAbs can detect activating mutations in the tyrosine kinase domain of EGFR by IHC of lung cancer tissues. ${ }^{131}$ Rabbit mAbs are also suitable to detect post-translational modifications. ${ }^{132,133}$ Further, rabbit mAbs against the HIV-1 protein gp120 were shown to mimic neutralizing human anti-HIV-1 gp120 mAbs, promoting rabbit immunization as model for HIV-1 vaccine development. ${ }^{94,134-136}$ 


\section{Phage display technology}

Bacteriophage, also simply known as phage, are viruses that infect and replicate within bacteria. Phage display was invented by George Smith, who discovered that the minor coat protein (pIII) of filamentous phage can be modified at its amino terminus to present peptide sequences without affecting phage infectivity. In addition, these phage particles contained the genomic information encoding the respectively modified coat protein, thus physically linking genotype and phenotype. A combination of phage selection and amplification could be used to efficiently enrich phage that contained certain peptide sequences. ${ }^{137}$ However, the incorporation of larger peptide sequences, protein domains or whole proteins represented a serious challenge due to decreasing infectivity. For this reason, two-component systems were developed that consisted of a phagemid encoding the pIII fusion protein and a helper phage contributing the phage genome to encode all proteins necessary for generating infectious phage particles. Usually, these helper phage contain a modified packaging signal, leading to the preferential assembly of phage particles containing the phagemid. In the early 1990s, the first filamentous phage display antibody libraries based on pIII fusion proteins were published using either scFv or Fab fragments. ${ }^{138,139}$ To date, these formats are still dominating the selection of mAbs by phage display. ${ }^{140-142}$

Although phage display was established with mouse and human antibody libraries to mine immune, naive and synthetic antibody repertoires, ${ }^{120,141}$ the fact that rabbit mAbs were difficult to generate by hybridoma technology for a number of years provided a strong incentive for exploring the accessibility of rabbit immune antibody repertoires by phage display. The first rabbit antibody library selected by phage display was reported by Ridder et al., ${ }^{143}$ using a scFv format as in subsequent independent studies. ${ }^{39,40,144-151}$ Rabbit antibody libraries in Fab format followed in short succession. ${ }^{152,153}$ Due to the higher expression levels of human compared to rabbit constant domains in bacteria, a chimeric rabbit/human Fab format consisting of rabbit variable domains VL and $\mathrm{VH}$ recombinantly fused to human constant domains CL and $\mathrm{CH} 1$, respectively, proved particularly successful for the selection of rabbit mAbs by phage display ${ }^{19,154-160}$ and their subsequent humanization (Figure 5). ${ }^{155}$ However, the abovediscussed intrachain disulfide bridge between cysteine 80 and cysteine 171 found in rabbit $\kappa$ light chains of the dominating K1 isotype posed a challenge to the chimeric rabbit/human Fab format as human $\mathrm{CH} 1$ does not harbor a cysteine 171. In fact, only few Fab originating from the $\mathrm{K} 1$ isotype were selected, ${ }^{86,155}$ indicating that the free thiol group of cysteine 80 is disfavored and that its presence diminishes the selectable diversity of chimeric rabbit/human Fab. Indeed, chimeric rabbit/human Fab derived by phage display from immunized K1-negative Basilea strain rabbits revealed higher sequence diversity and higher affinity compared to those from K1-positive New Zealand White strain rabbits immunized with the same immunogens. ${ }^{86}$ Interestingly, the same study by Popkov et al. also compared rabbits homozygous for the

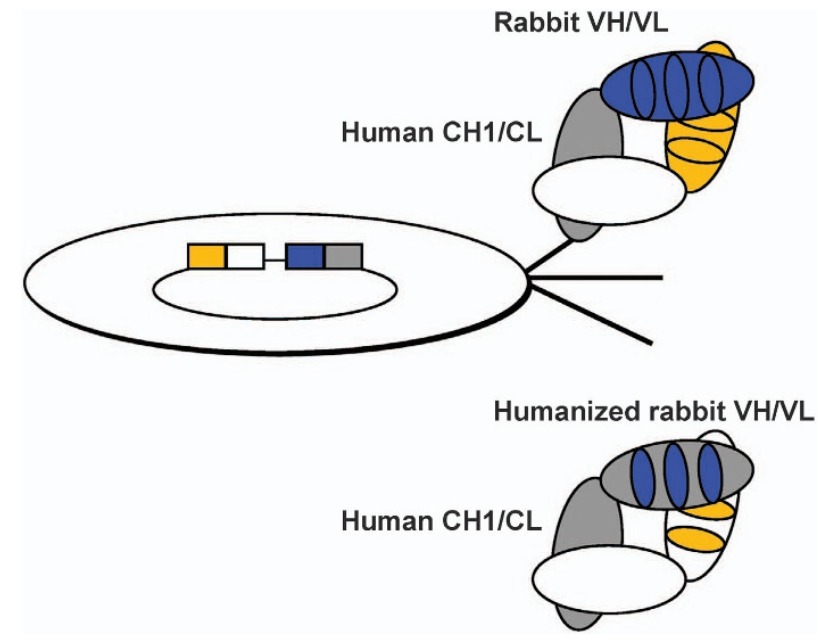

Figure 5 Chimeric rabbit/human Fab and humanized rabbit Fab. Top: in contrast to rabbit Fab, chimeric rabbit/human Fab, which consist of rabbit variable domains (blue and orange) and human constant domains (gray and white), are well expressed in Escherichia coli and displayed on phage. The phage particle shown displays one chimeric rabbit/human Fab copy linked to the phage surface by the C-terminal plll protein domain as its phenotype and, as its genotype, contain the corresponding single-stranded phagemid that encodes the Fab. This physical linkage of phenotype and genotype is the essence of phage display. Bottom: following selection by phage display, chimeric rabbit/human Fab can be humanized, which typically involves the grafting of the six rabbit CDRs (blue and orange) into human framework regions (gray and white).

b9 $\kappa$-light-chain allotype (Figure 1) with the presumed alternative intrachain disulfide bridge between cysteine 108 and

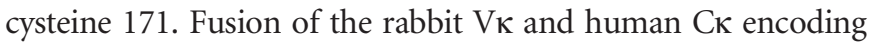
sequences in the generation of the chimeric rabbit/human Fab library removes cysteine 108, thus avoiding the exposure of a free thiol group. Consequently, immunized b9 allotype rabbits also revealed superior selectable diversity and were subsequently used in several additional studies. ${ }^{21,32,161}$ These include the generation of a chimeric rabbit/human Fab against the HIV-1 protein Rev. ${ }^{99}$ The Fab was able to invert Rev polymerization and allowed for the formation of Fab-Rev co-crystals that could be analyzed with X-ray crystallography providing the first three-dimensional structure of Rev and the first three-dimensional structure of a rabbit mAb. ${ }^{98}$ Notably, the crystal structure revealed a dominant role for LCDR3 in the antigen-binding site (Figure 6). A cyclic peptide derived from LCDR3 was shown to bind HIV-1 Rev with high affinity and to potently inhibit Rev polymerization, ${ }^{162}$ corroborating the functional importance of the above-discussed high sequence diversity of rabbit light chains.

A key advantage of using the natural Fab format for phage display is its robust monomeric nature that permits affinitydriven selections. ${ }^{142}$ By contrast, the unnatural $\mathrm{scFv}$ format has a tendency to dimerize, trimerize and tetramerize, ${ }^{163,164}$ potentially causing avidity-driven selections. ${ }^{141}$ Thus, we 


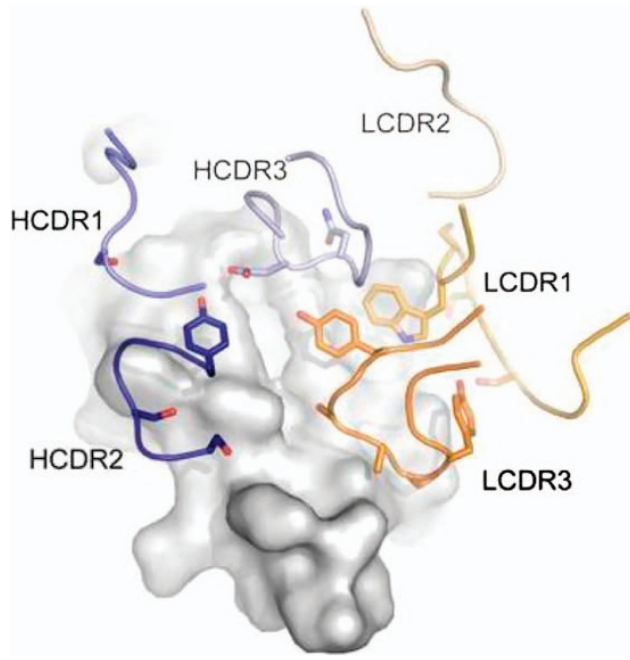

Figure 6 Crystal structure of a chimeric rabbit/human Fab selected by phage display in complex with HIV-1 Rev (PDB accession code 2X7L). ${ }^{98,99}$ The three CDR loops of the heavy chain are colored blue and the three CDR loops of the light chain are colored orange. Amino-acid residue side chains that interact with the antigen (gray) are drawn as sticks. Note the dominating contribution of LCDR3 to the paratope. When synthesized as cyclic peptide, LCDR3 on its own was able to bind HIV-1 Rev with high affinity. ${ }^{162}$

recommend using chimeric rabbit/human Fab format-based phage display for applications that require rabbit $\mathrm{mAbs}$ of high affinity. Even if the application calls for scFv, such as for the generation of intrabodies, the chimeric rabbit/human Fab format has been used for selection by phage display followed by conversion to the rabbit scFv format. ${ }^{160,165-167}$ In addition to Fab and scFv formats, single-domain antibody formats, that is, $\mathrm{VL}$ or $\mathrm{VH}$ alone, which due to their smaller sizes have advantages for certain applications, such as the recognition of cryptic epitopes, ${ }^{163}$ have also been engineered from rabbit mAbs. ${ }^{168-170}$ The noted dominance of the rabbit light chain may make phage display of rabbit VL libraries particularly attractive.

\section{Alternative methods}

As discussed, hybridoma technology and phage display have distinct virtues and shortcomings that have fueled the development of alternative techniques to generate mAbs. Unlike hybridoma technology, phage display relies on the proper transcription, translation, folding and assembly of light and heavy chains in bacteria. Also, a potential disadvantage of phage display, as well as other display technologies, is their combinatorial nature, leading to the random pairing of light and heavy chains. ${ }^{120}$ As discussed above, limiting factors encountered during hybridoma technology, at least initially, included fusion efficiency and hybridoma stability. ${ }^{130,171}$ Also, unlike mouse hybridoma technology, rabbit hybridoma technology was patented, imposing intellectual property restrictions that have contributed to the incentive of developing alternative methods.
In the generation of human mAbs, prominent alternative methods include the clonal expansion of $\mathrm{B}$ cells by, for example, Epstein-Barr virus immortalization, and single B-cell sorting followed by light- and heavy-chain-encoding DNA amplification and sequencing. ${ }^{120}$ Notably, like hybridoma technology but unlike phage display, both methods yield natural light- and heavy-chain pairs. Single B-cell isolation based on antigen capture by fluorescence-activated cell sorting, magnetic beads, solid-phase panning or hemolytic plaques followed by light- and heavy-chain cloning has also been applied to the generation of rabbit mAbs from peripheral $\mathrm{B}$ cells, ${ }^{172-176}$ which does not require killing of the animal and allows for multiple sampling points from primary and secondary lymphoid tissues. ${ }^{177}$ Antigen capture-driven bulk spleen B-cell isolation from immunized rabbits followed by light- and heavy-chain-encoding DNA amplification and their combinatorial assembly and expression in $\mathrm{scFv}-\mathrm{Fc}$ or IgG format in mammalian cells has also been reported. ${ }^{178}$ In the fluorescent foci method, plasma cells from rabbit bone marrow are identified by fluorescent microscopy, isolated and subjected to light- and heavy-chain-encoding DNA amplification and sequencing. ${ }^{179}$

High-throughput DNA sequencing technologies have been applied to the in silico generation of mAbs as well as to the analysis of naive and immune antibody repertoires in different species. ${ }^{180}$ In the rabbit, high-throughput DNA sequencing of B-cell repertoires along with mass spectrometry analysis of bulk serum IgG has been used for the deconvolution of mAbs. ${ }^{64,181}$ Interestingly, this method revealed that the serum IgG response to an invertebrate protein following hyperimmunization was oligoclonal rather than polyclonal, comprising 34 rabbit mAbs belonging to 30 distinct clonotypes. ${ }^{64}$

\section{HUMANIZATION OF RABBIT MABS}

The human immune system is intended to recognize and selectively remove potentially pathogenic organisms and substances. This is also true for nonhuman proteins, such as mouse and rabbit mAbs. The respective immune responses are characterized by high titers of human antibodies directed against these foreign antibody sequences. ${ }^{182}$ This has two main physiological consequences; first of all, it leads to side effects comparable to allergic reactions of different levels of severity and, second, it leads to the rapid elimination of the administered $\mathrm{mAb}$, thus limiting its diagnostic or therapeutic efficacy. ${ }^{183,184}$ For these reasons, nonhuman mAbs are now routinely converted to chimeric mAbs by combining the nonhuman variable domains with human constant domains $^{185}$ and further to humanized mAbs by grafting all or some of the CDRs of the nonhuman variable domains into human frameworks. ${ }^{186}$

The first chimeric and humanized rabbit mAbs were reported by Rader et al. ${ }^{155}$ In this study, chimeric rabbit/ human Fab selected by phage display were humanized by grafting the six rabbit CDRs, three from each light and heavy chain, into human frameworks that were diversified at certain positions to allow the selection of either human or rabbit 
residues by phage display. The resulting humanized rabbit mAbs retained the high affinity and specificity of their parental mAbs. As discussed above, aside from having higher utility for downstream clinical applications, using chimeric rabbit/human Fab format for phage display has the added advantage of affording higher expression levels in bacteria and, concomitantly, higher display levels on phage. ${ }^{155}$

Since this first report, a number of additional humanized rabbit mAbs have been published and patented. In general, humanization strategies that have worked for mouse mAbs also work for rabbit mAbs, whether it is by rational design, ${ }^{17,33,187}$ directed evolution ${ }^{188}$ or a combination of both. ${ }^{155,189}$ As is the case for mouse mAbs, grafting of all six CDRs followed by iterative fine-tuning of framework residues is the most frequently used method for humanizing rabbit mAbs. Borras et al. used a general acceptor framework for the humanization of rabbit scFv. In this study, a certain human framework carrying five specific human-to-rabbit mutations was able to generate humanized rabbit mAbs to two different antigens with conserved affinities and specificities, and improved biophysical properties. ${ }^{24}$ Humanization strategies that confine the content of parental rabbit antibody sequences only to the most hypervariable of the CDRs, such as LCDR3 and HCDR $3,{ }^{190}$ have also been successfully applied to rabbit mAbs. ${ }^{188}$

Thus far, there have been no reports that analyze the immunogenicity of clinically investigated humanized rabbit mAbs. Recent studies indicate that patients can still mount an immune response to humanized or even fully human mAbs. These findings indicate that additional aspects, such as idiotype, allotype, glycosylation and aggregation, contribute to the immunogenicity of mAbs. ${ }^{191}$ Nonetheless, the occurrence of these unwanted side effects is significantly lower than previously observed for nonhuman antibodies. ${ }^{182}$

\section{SUMMARY AND OUTLOOK}

Driven by the success of rabbit pAbs on one hand and mouse mAbs on the other hand, rabbit mAbs have become highly successful reagents for laboratory research and for diagnostic and therapeutic applications. The unique ontogeny of rabbit $B$ cells affords highly distinctive antibody repertoires rich in in vivo pruned binders of high diversity, affinity and specificity. The ability to access rabbit antibody repertoires by hybridoma technology, phage display and alternative methods has fueled the increased use of rabbit mAbs in many different applications. Rabbit mAbs generated by hybridoma technology are particularly attractive for IHC, with many studies demonstrating higher sensitivity compared to benchmark mouse mAbs. Rabbit $m A b s$ generated by phage display have found the use for applications ranging from the detection of uranium in water ${ }^{40}$ to chimeric antigen receptor $\mathrm{T}$ cell therapy of cancer. ${ }^{22}$ Given that humanization strategies are now well established, the therapeutic utility of rabbit mAbs is especially intriguing. With the first rabbit $\mathrm{mAb}$-derived therapeutics already in clinical trials, we predict that rabbit mAbs will gain further traction in preclinical and clinical pipelines over the next decade.

\section{CONFLICT OF INTEREST}

The authors declare no conflict of interest.

\section{ACKNOWLEDGEMENTS}

We thank Dr HaJeung Park for preparing Figure 6, and Drs Rose G. Mage and Weimin Zhu for reading and editing the manuscript.

1 Pinheiro A, Neves F, Lemos De Matos A, Abrantes J, Van Der Loo W, Mage $\mathrm{R}$ et al. An overview of the lagomorph immune system and its genetic diversity. Immunogenetics 2016; 68: 83-107.

2 Mage RG, Lanning D, Knight KL. B cell and antibody repertoire development in rabbits: the requirement of gut-associated lymphoid tissues. Dev Comp Immunol 2006; 30: 137-153.

3 Haurum JS. Recombinant polyclonal antibodies: the next generation of antibody therapeutics? Drug Discov Today 2006; 11: 655-660.

4 Campbell K, Stewart LD, Doucette GJ, Fodey TL, Haughey SA, Vilarino N et al. Assessment of specific binding proteins suitable for the detection of paralytic shellfish poisons using optical biosensor technology. Anal Chem 2007; 79: 5906-5914.

5 Mohty M, Gaugler B. Mechanisms of action of antithymocyte globulin: old dogs with new tricks!. Leuk Lymphoma 2008; 49: 1664-1667.

6 Thomas FT, Griesedieck C, Thomas J, Carver M, Whitley T, Warren R et al. Differential effects of horse ATG and rabbit ATG on T cell and T cell subset levels measured by monoclonal antibodies. Transplant Proc 1984; 16: 1561-1563.

7 Zhu L, Fang Y, Liu Z, Wang P, Wang Y, Xu H. Rabbit anti-human leukocyte polyclonal antibody inhibits xenogeneic cell-mediated immune responses. Transplant Proc 2008; 40: 2760-2763.

8 FDA. Available at http://www.accessdata.fda.gov/scripts/cdrh/devicesatfda/ index.cfm (using search term 'rabbit polyclonal antibodies', accessed on 3 October 2016).

9 Reichert JM. Antibodies to watch in 2016. MAbs 2016; 8: 197-204.

10 Weiner GJ. Building better monoclonal antibody-based therapeutics. Nat Rev Cancer 2015; 15: 361-370.

11 Chan AC, Carter PJ. Therapeutic antibodies for autoimmunity and inflammation. Nat Rev Immunol 2010; 10: 301-316.

12 Scott AM, Wolchok JD, Old LJ. Antibody therapy of cancer. Nat Rev Cancer 2012; 12: 278-287.

13 FDA. Available at http://www.accessdata.fda.gov/scripts/cdrh/devicesatfda/index.cfm (using search term 'rabbit monoclonal antibody', accessed on 3 October 2016).

14 Zhu W, Li A, Chen T Rabbit monoclonal antibodies. In: Lin F, Prichard J (eds). Handbook of Practical Immunohistochemistry: Frequently Asked Questions. Springer-Verlag: New York, NY, USA, 2015, pp 77-84.

15 Scher HI, Lu D, Schreiber NA, Louw J, Graf RP, Vargas HA et al. Association of AR-V7 on circulating tumor cells as a treatment-specific biomarker with outcomes and survival in castration-resistant prostate cancer. JAMA Oncol 2016; 2: 1441-1449.

16 Welti J, Rodrigues DN, Sharp A, Sun S, Lorente D, Riisnaes R et al. Analytical validation and clinical qualification of a new immunohistochemical assay for androgen receptor splice variant-7 protein expression in metastatic castration-resistant prostate cancer. Eur Urol 2016; 70: 599-608.

17 Yu Y, Lee $P$, Ke Y, Zhang Y, Yu Q, Lee J et al. A humanized anti-VEGF rabbit monoclonal antibody inhibits angiogenesis and blocks tumor growth in xenograft models. PLOS ONE 2010; 5: e9072.

18 Feng L, Wang X, Jin H. Rabbit monoclonal antibody: potential application in cancer therapy. Am J Trans/ Res 2011; 3: 269-274.

19 Kim K, Hur Y, Ryu EK, Rhim JH, Choi CY, Baek CM et al. A neutralizable epitope is induced on HGF upon its interaction with its receptor cMet. Biochem Biophys Res Commun 2007; 354: 115-121.

20 Song SW, Lee SJ, Kim CY, Song JK, Jung EJ, Choi YB et al. Inhibition of tumor growth in a mouse xenograft model by the humanized anti-HGF monoclonal antibody YYB-101 produced in a large-scale $\mathrm{CHO}$ cell culture. J Microbiol Biotechnol 2013; 23: 1327-1338.

21 Yang J, Baskar S, Kwong KY, Kennedy MG, Wiestner A, Rader C. Therapeutic potential and challenges of targeting receptor tyrosine kinase ROR1 with monoclonal antibodies in B-cell malignancies. PLOS ONE 2011; 6: e21018. 
22 Hudecek M, Lupo-Stanghellini MT, Kosasih PL, Sommermeyer D, Jensen MC, Rader C et al. Receptor affinity and extracellular domain modifications affect tumor recognition by ROR1-specific chimeric antigen receptor T cells. Clin Cancer Res 2013; 19: 3153-3164.

23 Berger C, Sommermeyer D, Hudecek M, Berger M, Balakrishnan A, Paszkiewicz PJ et al. Safety of targeting ROR1 in primates with chimeric antigen receptor-modified $T$ cells. Cancer Immunol Res 2015; 3: 206-216.

24 Borras L, Gunde T, Tietz J, Bauer U, Hulmann-Cottier V, Grimshaw JP et al. Generic approach for the generation of stable humanized singlechain Fv fragments from rabbit monoclonal antibodies. J Biol Chem 2010; 285: 9054-9066.

25 Ayyar BV, Hearty S, O'kennedy R. Facile domain rearrangement abrogates expression recalcitrance in a rabbit scFv. Appl Microbiol Biotechnol 2015; 99: 2693-2703.

26 Miller W, Rosenbloom K, Hardison RC, Hou M, Taylor J, Raney B et al. 28-way vertebrate alignment and conservation track in the UCSC Genome Browser. Genome Res 2007; 17: 1797-1808.

27 Matthee CA, Van Vuuren BJ, Bell D, Robinson TJ. A molecular supermatrix of the rabbits and hares (Leporidae) allows for the identification of five intercontinental exchanges during the Miocene. Syst Biol 2004; 53: 433-447.

28 Carneiro M, Afonso S, Geraldes A, Garreau H, Bolet G, Boucher S et al. The genetic structure of domestic rabbits. Mol Biol Evol 2011; 28: 1801-1816.

29 Melo-Ferreira J, Lemos De Matos A, Areal H, Lissovsky AA, Carneiro M, Esteves PJ. The phylogeny of pikas (Ochotona) inferred from a multilocus coalescent approach. Mol Phylogenet Evol 2015; 84: 240-244.

30 Rief N, Waschow C, Nastainczyk W, Montenarh M, Gotz C. Production and characterization of a rabbit monoclonal antibody against human CDC25C phosphatase. Hybridoma 1998; 17: 389-394.

31 Yu Y, Chen Y, Ding G, Wang M, Wu H, Xu L et al. A novel rabbit antihepatocyte growth factor monoclonal neutralizing antibody inhibits tumor growth in prostate cancer cells and mouse xenografts. Biochem Biophys Res Commun 2015; 464: 154-160.

32 Popkov M, Jendreyko N, Gonzalez-Sapienza G, Mage RG, Rader C, Barbas CF 3rd. Human/mouse cross-reactive anti-VEGF receptor 2 recombinant antibodies selected from an immune b9 allotype rabbit antibody library. J Immunol Methods 2004; 288: 149-164.

$33 \mathrm{Yu}$ Y, Lee P, Ke Y, Zhang Y, Chen J, Dai J et al. Development of humanized rabbit monoclonal antibodies against vascular endothelial growth factor receptor 2 with potential antitumor effects. Biochem Biophys Res Commun 2013; 436: 543-550.

34 Lu Y, Su Z, Li Y, Luo J, Tan Z, Ji H et al. Generation and characterisation of rabbit monoclonal antibodies against the native cell surface antigens of embryonic stem cells. J Genet Genomics 2010; 37: 483-492.

35 Tan Z, Zhang J, Su Z, Gu B, Jiang X, Luo J et al. Production of rabbit monoclonal antibodies against mouse embryonic stem cells and identification of pluripotency-associated surface antigens. J Immunol Methods 2011; 365: 149-157.

36 Huang Y, Gu B, Wu R, Zhang J, Li Y, Zhang M. Development of a rabbit monoclonal antibody group against Smads and immunocytochemical study of human and mouse embryonic stem cells. Hybridoma 2007; 26: 387-391.

37 Liu N, Zhao Z, Tan Y, Lu L, Wang L, Liao Y et al. Simultaneous raising of rabbit monoclonal antibodies to fluoroquinolones with diverse recognition functionalities via single mixture immunization. Anal Chem 2016; 88: 1246-1252.

38 Liu N, Han Z, Lu L, Wang L, Ni G, Zhao Z et al. Development of a new rabbit monoclonal antibody and its based competitive indirect enzymelinked immunosorbent assay for rapid detection of sulfonamides. J Sci Food Agric 2013; 93: 667-673.

39 Li Y, Cockburn W, Kilpatrick JB, Whitelam GC. High affinity ScFvs from a single rabbit immunized with multiple haptens. Biochem Biophys Res Commun 2000; 268: 398-404.

40 Zhu X, Kriegel AM, Boustany CA, Blake DA. Single-chain variable fragment (scFv) antibodies optimized for environmental analysis of uranium. Anal Chem 2011; 83: 3717-3724.

41 Medical Device and Diagnostic Industry. Rabbit monoclonal antibody: a new diagnostics technology. Available at http://www.mddionline.com/ article/rabbit-monoclonal-antibody-new-diagnostics-technology (posted on 26 June 2013 by Weimin Zhu).
42 Peng X, Roshwalb S, Cooper TK, Zimmerman H, Christensen ND. High incidence of spontaneous cataracts in aging laboratory rabbits of an inbred strain. Vet Ophthalmol 2015; 18: 186-190.

43 Klebe S, Swalling A, Jonavicius L, Henderson DW. An immunohistochemical comparison of two TTF-1 monoclonal antibodies in atypical squamous lesions and sarcomatoid carcinoma of the lung, and pleural malignant mesothelioma. J Clin Pathol 2016; 69: 136-141.

44 Hoang LL, Tang $\mathrm{P}$, Hicks DG, Chen H, Yang Q, Haas TS et al. A new rabbit monoclonal E-cadherin antibody [EP700Y] shows higher sensitivity than mouse monoclonal E-cadherin [HECD-1] antibody in breast ductal carcinomas and does not stain breast lobular carcinomas. Appl Immunohistochem Mol Morphol 2014; 22: 606-612.

45 Fortunato MJ, Ball CE, Hollinger K, Patel NB, Modi JN, Rajasekaran V et al. Development of rabbit monoclonal antibodies for detection of alphadystroglycan in normal and dystrophic tissue. PLOS ONE 2014; 9: e97567.

46 Kendrick SL, Redd L, Muranyi A, Henricksen LA, Stanislaw S, Smith LM et al. BCL2 antibodies targeted at different epitopes detect varying levels of protein expression and correlate with frequent gene amplification in diffuse large B-cell lymphoma. Hum Pathol 2014; 45: 2144-2153.

47 Boger C, Kalthoff H, Goodman SL, Rocken C. Validation and comparison of anti-alphavbeta3 and anti-alphavbeta5 rabbit monoclonal versus murine monoclonal antibodies in four different tumor entities. Appl Immunohistochem Mol Morphol 2013; 21: 553-560.

48 Taheri D, Zahavi DJ, Del Carmen Rodriguez M, Meliti A, Rezaee N, Yonescu R et al. For staining of ALK protein, the novel D5F3 antibody demonstrates superior overall performance in terms of intensity and extent of staining in comparison to the currently used ALK1 antibody. Virchows Arch 2016; 469: 345-350.

49 Hanley KZ, Siddiqui MT, Lawson D, Cohen C, Nassar A. Evaluation of new monoclonal antibodies in detection of estrogen receptor, progesterone receptor, and Her2 protein expression in breast carcinoma cell block sections using conventional microscopy and quantitative image analysis. Diagn Cytopathol 2009; 37: 251-257.

50 Rocha R, Nunes C, Rocha G, Oliveira F, Sanches F, Gobbi H. Rabbit monoclonal antibodies show higher sensitivity than mouse monoclonals for estrogen and progesterone receptor evaluation in breast cancer by immunohistochemistry. Pathol Res Pract 2008; 204: 655-662.

51 Rossi S, Laurino L, Furlanetto A, Chinellato S, Orvieto E, Canal F et al. Rabbit monoclonal antibodies: a comparative study between a novel category of immunoreagents and the corresponding mouse monoclonal antibodies. Am J Clin Pathol 2005; 124: 295-302.

52 Cheuk W, Wong KO, Wong CS, Chan JK. Consistent immunostaining for cyclin D1 can be achieved on a routine basis using a newly available rabbit monoclonal antibody. Am J Surg Pathol 2004; 28: 801-807.

53 Pruneri G, Valentini S, Bertolini F, Del Curto B, Maiorano E, Viale G. SP4, a novel anti-cyclin D1 rabbit monoclonal antibody, is a highly sensitive probe for identifying mantle cell lymphomas bearing the $\mathrm{t}(11 ; 14)$ (q13;q32) translocation. Appl Immunohistochem Mol Morphol 2005; 13: 318-322.

54 Huang Z, Zhu W, Meng Y, Xia H. Development of new rabbit monoclonal antibody to progesterone receptor (Clone SP2): no heat pretreatment but effective for paraffin section immunohistochemistry. App/ Immunohistochem Mol Morphol 2006; 14: 229-233.

55 Cheang MC, Treaba DO, Speers CH, Olivotto IA, Bajdik CD, Chia SK et al. Immunohistochemical detection using the new rabbit monoclonal antibody SP1 of estrogen receptor in breast cancer is superior to mouse monoclonal antibody 1D5 in predicting survival. J Clin Oncol 2006; 24: 5637-5644.

56 Guo Q, Li H, Gaddam SS, Justice NJ, Robertson CS, Zheng H. Amyloid precursor protein revisited: neuron-specific expression and highly stable nature of soluble derivatives. J Biol Chem 2012; 287: 2437-2445.

57 Van Der Vegt B, De Bock GH, Bart J, Zwartjes NG, Wesseling J. Validation of the 4B5 rabbit monoclonal antibody in determining Her2/neu status in breast cancer. Mod Pathol 2009; 22: 879-886.

58 Fischer T, Nagel F, Jacobs S, Stumm R, Schulz S. Reassessment of CXCR4 chemokine receptor expression in human normal and neoplastic tissues using the novel rabbit monoclonal antibody UMB-2. PLOS ONE 2008; 3: e4069.

59 Qi W, Chu J, Zhou D, Tacha D. Characterization and applications of a newly developed rabbit monoclonal antibody to cytokeratin 7 (CK7) for immunohistochemistry. Appl Immunohistochem Mol Morphol 2009; 17: 233-238. 
60 Wludarski SC, Bacchi CE. High concordance of SP3 rabbit monoclonal antibody with FISH to evaluate HER2 in breast carcinoma. Appl Immunohistochem Mol Morphol 2008; 16: 466-470.

61 Powell WC, Hicks DG, Prescott N, Tarr SM, Laniauskas S, Williams T et al. A new rabbit monoclonal antibody (4B5) for the immunohistochemical (IHC) determination of the HER2 status in breast cancer: comparison with CB11, fluorescence in situ hybridization (FISH), and interlaboratory reproducibility. Appl Immunohistochem Mol Morphol 2007; 15: 94-102.

62 Ricardo SA, Milanezi F, Carvalho ST, Leitao DR, Schmitt FC. HER2 evaluation using the novel rabbit monoclonal antibody SP3 and $\mathrm{CISH}$ in tissue microarrays of invasive breast carcinomas. J Clin Pathol 2007; 60: 1001-1005.

63 Landry JP, Ke Y, Yu GL, Zhu XD. Measuring affinity constants of 1450 monoclonal antibodies to peptide targets with a microarray-based label-free assay platform. J Immunol Methods 2015; 417: 86-96.

64 Wine Y, Boutz DR, Lavinder JJ, Miklos AE, Hughes RA, Hoi KH et al. Molecular deconvolution of the monoclonal antibodies that comprise the polyclonal serum response. Proc Natl Acad Sci USA 2013; 110: 2993-2998.

65 Carneiro M, Rubin CJ, Di Palma F, Albert FW, Alfoldi J, Barrio AM et al. Rabbit genome analysis reveals a polygenic basis for phenotypic change during domestication. Science 2014; 345: 1074-1079.

66 Gertz EM, Schaffer AA, Agarwala R, Bonnet-Garnier A, Rogel-Gaillard C, Hayes $\mathrm{H}$ et al. Accuracy and coverage assessment of Oryctolagus cuniculus (rabbit) genes encoding immunoglobulins in the whole genome sequence assembly (OryCun2.0) and localization of the IGH locus to chromosome 20. Immunogenetics 2013; 65: 749-762.

67 Knight KL, Crane MA. Generating the antibody repertoire in rabbit. Adv Immunol 1994; 56: 179-218.

68 Tunyaplin C, Knight KL. Fetal VDJ gene repertoire in rabbit: evidence for preferential rearrangement of VH1. Eur J Immunol 1995; 25: 2583-2587.

69 Zhu X, Boonthum A, Zhai SK, Knight KL. B lymphocyte selection and agerelated changes in $\mathrm{VH}$ gene usage in mutant Alicia rabbits. J Immunol 1999; 163: 3313-3320.

70 Crane MA, Kingzette M, Knight KL. Evidence for limited B-lymphopoiesis in adult rabbits. J Exp Med 1996; 183: 2119-2121.

71 Sehgal D, Schiaffella E, Anderson AO, Mage RG. Analyses of single B cells by polymerase chain reaction reveal rearranged $\mathrm{VH}$ with germline sequences in spleens of immunized adult rabbits: implications for B cell repertoire maintenance and renewal. J Immunol 1998; 161: 5347-5356.

72 Yoshio T, Saito K, Adler FL, Adler LT. A role for mature B cells in bone marrow transplantation. Immunology 1988; 64: 147-153.

73 Lanning D, Zhu X, Zhai SK, Knight KL. Development of the antibody repertoire in rabbit: gut-associated lymphoid tissue, microbes, and selection. Immunol Rev 2000; 175: 214-228.

74 Gathings WE, Mage RG, Cooper MD, Lawton AR, Young-Cooper GO. Immunofluorescence studies on the expression of $\mathrm{VH}$ a allotypes by pre-B and B cells of homozygous and heterozygous rabbits. Eur J Immunol 1981; 11: 200-206.

75 Ehlich A, Schaal S, Gu H, Kitamura D, Muller W, Rajewsky K. Immunoglobulin heavy and light chain genes rearrange independently at early stages of B cell development. Cell 1993; 72: 695-704.

76 Sehgal D, Johnson G, Wu TT, Mage RG. Generation of the primary antibody repertoire in rabbits: expression of a diverse set of lgk-V genes may compensate for limited combinatorial diversity at the heavy chain locus. Immunogenetics 1999; 50: 31-42.

77 Roux KH, Dhanarajan P, Gottschalk V, Mccormick WT, Renshaw RW. Latent a1 $\mathrm{VH}$ germline genes in an a2a2 rabbit. Evidence for gene conversion at both the germline and somatic levels. J Immunol 1991; 146: 2027-2036.

78 Fitts MG, Metzger DW. Identification of rabbit genomic Ig-VH pseudogenes that could serve as donor sequences for latent allotype expression. J Immunol 1990; 145: 2713-2717.

79 Friedman ML, Tunyaplin C, Zhai SK, Knight KL. Neonatal VH, D, and JH gene usage in rabbit B lineage cells. J Immunol 1994; 152: 632-641.

80 Becker RS, Suter M, Knight KL. Restricted utilization of VH and DH genes in leukemic rabbit B cells. Eur J Immunol 1990; 20: 397-402.

81 Dray S, Young GO, Nisonoff A. Distribution of allotypic specificities among rabbit gamma-globulin molecules genetically defined at two loci. Nature 1963; 199: 52-55.

$82 \mathrm{Kim}$ BS, Dray S. Expression of the a, $\mathrm{x}$, and $\mathrm{y}$ variable region genes of heavy chains among IgG, IgM, and IgA molecules of normal and a locus allotype-suppressed rabbits. J Immunol 1973; 111: 750-760.
83 Short JA, Sethupathi P, Zhai SK, Knight KL. VDJ genes in VHa2 allotypesuppressed rabbits. Limited germline $\mathrm{VH}$ gene usage and accumulation of somatic mutations in D regions. J Immunol 1991; 147: 4014-4018.

84 Dipietro LA, Knight KL. Restricted utilization of germ-line VH genes and diversity of D regions in rabbit splenic Ig mRNA. J Immunol 1990; 144: 1969-1973.

85 Lavinder JJ, Hoi KH, Reddy ST, Wine Y, Georgiou G. Systematic characterization and comparative analysis of the rabbit immunoglobulin repertoire. PLOS ONE 2014; 9: e101322.

86 Popkov M, Mage RG, Alexander CB, Thundivalappil S, Barbas CF 3rd, Rader $\mathrm{C}$. Rabbit immune repertoires as sources for therapeutic monoclonal antibodies: the impact of kappa allotype-correlated variation in cysteine content on antibody libraries selected by phage display. $J \mathrm{Mol}$ Biol 2003; 325: 325-335.

87 Benammar A, Cazenave PA. A second rabbit kappa isotype. J Exp Med 1982; 156: 585-595.

88 Bernstein KE, Skurla RM Jr., Mage RG. The sequences of rabbit kappa light chains of b4 and b5 allotypes differ more in their constant regions than in their $3^{\prime}$ untranslated regions. Nucleic Acids Res 1983; 11: 7205-7214.

89 Mage RG. Diversification of rabbit VH genes by gene-conversion-like and hypermutation mechanisms. Immunol Rev 1998; 162: 49-54.

90 Mccartney-Francis N, Skurla RM Jr., Mage RG, Bernstein KE. Kappachain allotypes and isotypes in the rabbit: cDNA sequences of clones encoding b9 suggest an evolutionary pathway and possible role of the interdomain disulfide bond in quantitative allotype expression. Proc Natl Acad Sci USA 1984; 81: 1794-1798.

91 Poulsen K, Fraser KJ, Haber E. An active derivative of rabbit antibody light chain composed of the constant and the variable domains held together only by a native disulfide bond. Proc Natl Acad Sci USA 1972; 69: 2495-2499.

92 Strosberg AD, Margolies MN, Haber E. The interdomain disulfide bond of a homogeneous rabbit pneumococcal antibody light chain. J Immunol 1975; 115: 1422-1424.

93 Arai $\mathrm{H}$, Glabe $\mathrm{C}$, Luecke $\mathrm{H}$. Crystal structure of a conformation-dependent rabbit IgG Fab specific for amyloid prefibrillar oligomers. Biochim Biophys Acta 2012; 1820: 1908-1914.

94 Pan R, Sampson JM, Chen Y, Vaine M, Wang S, Lu S et al. Rabbit antiHIV-1 monoclonal antibodies raised by immunization can mimic the antigen-binding modes of antibodies derived from HIV-1infected humans. J Virol 2013; 87: 10221-10231.

95 Ros F, Reichenberger N, Dragicevic T, Van Schooten WC, Buelow R, Platzer J. Sequence analysis of 0.4 megabases of the rabbit germline immunoglobulin kappa1 light chain locus. Anim Genet 2005; 36: 51-57.

96 Kodangattil S, Huard C, Ross C, Li J, Gao H, Mascioni A et al. The functional repertoire of rabbit antibodies and antibody discovery via nextgeneration sequencing. MAbs 2014; 6: 628-636.

97 Malia TJ, Teplyakov A, Brezski RJ, Luo J, Kinder M, Sweet RW et al. Structure and specificity of an antibody targeting a proteolytically cleaved IgG hinge. Proteins 2014; 82: 1656-1667.

98 Dimattia MA, Watts NR, Stahl SJ, Rader C, Wingfield PT, Stuart DI et al. Implications of the HIV-1 Rev dimer structure at 3.2 A resolution for multimeric binding to the Rev response element. Proc Natl Acad Sci USA 2010; 107: 5810-5814.

99 Stahl SJ, Watts NR, Rader C, Dimattia MA, Mage RG, Palmer I et al. Generation and characterization of a chimeric rabbit/human Fab for co-crystallization of HIV-1 Rev. J Mol Biol 2010; 397: 697-708.

100 Lammens A, Baehner M, Kohnert U, Niewoehner J, Von Proff L, Schraeml $\mathrm{M}$ et al. Crystal structure of human TWEAK in complex with the Fab fragment of a neutralizing antibody reveals insights into receptor binding. PLOS ONE 2013; 8: e62697.

101 Sun J, Hayward C, Shinde R, Christenson R, Ford SP, Butler JE. Antibody repertoire development in fetal and neonatal piglets. I. Four VH genes account for 80 percent of $\mathrm{VH}$ usage during 84 days of fetal life. J Immunol 1998; 161: 5070-5078.

102 Mage RG, Sehgal D, Schiaffella E, Anderson AO. Gene-conversion in rabbit B-cell ontogeny and during immune responses in splenic germinal centers. Vet Immunol Immunopathol 1999; 72: 7-15.

103 Raman C, Spieker-Polet H, Yam PC, Knight KL. Preferential VH gene usage in rabbit Ig-secreting heterohybridomas. J Immunol 1994; 152: 3935-3945.

104 Lanning DK, Knight KL. Somatic hypermutation: mutations 3' of rabbit VDJ H-chain genes. J Immunol 1997; 159: 4403-4407.

105 Kurosawa K, Ohta K. Genetic diversification by somatic gene conversion. Genes 2011; 2: 48-58. 
106 Weinstein PD, Anderson AO, Mage RG. Rabbit IgH sequences in appendix germinal centers: $\mathrm{VH}$ diversification by gene conversion-like and hypermutation mechanisms. Immunity 1994; 1: 647-659.

107 Pascual V, Verkruyse L, Casey ML, Capra JD. Analysis of Ig H chain gene segment utilization in human fetal liver. Revisiting the 'proximal utilization hypothesis'. J Immunol 1993; 151: 4164-4172.

108 Sehgal D, Schiaffella E, Anderson AO, Mage RG. Generation of heterogeneous rabbit anti-DNP antibodies by gene conversion and hypermutation of rearranged $\mathrm{VL}$ and $\mathrm{VH}$ genes during clonal expansion of $\mathrm{B}$ cells in splenic germinal centers. Eur J Immunol 2000; 30: 3634-3644.

109 Trier JS. Structure and function of intestinal M cells. Gastroenterol Clin North Am 1991; 20: 531-547.

110 Cooper MD, Perey DY, Mckneally MF, Gabrielsen AE, Sutherland DE, Good RA. A mammalian equivalent of the avian bursa of Fabricius. Lancet 1966; 1: 1388-1391.

111 Bockman DE. Functional histology of appendix. Arch Histol Jpn 1983; 46: 271-292.

112 Štěpánková R, Kovářů F. Immunoglobulin-producing cells in lymphatic tissues of germfree and conventional rabbits as detected by an immunofluorescence method. Folia Microbiol 1985; 30: 291-294.

113 Tlaskalova-Hogenova H, Stepankova R. Development of antibody formation in germ-free and conventionally reared rabbits: the role of intestinal lymphoid tissue in antibody formation to E. coli antigens. Folia Biol 1980; 26: 81-93.

114 Lanning D, Sethupathi P, Rhee KJ, Zhai SK, Knight KL. Intestinal microflora and diversification of the rabbit antibody repertoire. J Immunol 2000; 165: 2012-2019.

115 Winstead CR, Zhai SK, Sethupathi P, Knight KL. Antigen-induced somatic diversification of rabbit IgH genes: gene conversion and point mutation. $J$ Immunol 1999; 162: 6602-6612.

116 Schiaffella E, Sehgal D, Anderson AO, Mage RG. Gene conversion and hypermutation during diversification of $\mathrm{VH}$ sequences in developing splenic germinal centers of immunized rabbits. J Immunol 1999; 162: 3984-3995.

117 Spieker-Polet H, Yam PC, Knight KL. Differential expression of 13 IgAheavy chain genes in rabbit lymphoid tissues. J Immunol 1993; 150: 5457-5465.

118 Margulies DH. Monoclonal antibodies: producing magic bullets by somatic cell hybridization. J Immunol 2005; 174: 2451-2452.

119 Kohler G, Milstein C. Continuous cultures of fused cells secreting antibody of predefined specificity. Nature 1975; 256: 495-497.

120 Beerli RR, Rader C. Mining human antibody repertoires. MAbs 2010; 2 . 365-378.

121 Zhu W, Yu GL Rabbit hybdridoma. In: An, Z (ed.) Therapeutic Monoclonal Antibodies: From Bench to Clinic. John Wiley \& Sons: Hoboken, NJ, USA, 2009, pp 151-168.

122 Raybould TJ, Takahashi M. Production of stable rabbit-mouse hybridomas that secrete rabbit mAb of defined specificity. Science 1988; 240: 1788-1790.

123 Collins JJ, Black PH, Strosberg AD, Haber E, Bloch KJ. Transformation by simian virus 40 of spleen cells from a hyperimmune rabbit: evidence for synthesis of immunoglobulin by the transformed cells. Proc Natl Acad Sci USA 1974; 71: 260-262.

124 Buttin G, Leguern G, Phalente L, Lin EC, Medrano L, Cazenave PA. Production of hybrid lines secreting monoclonal anti-idiotypic antibodies by cell fusion on membrane filters. Curr Top Microbiol Immunol 1978; 81: 27-36.

125 Yarmush ML, Gates FT 3rd, Weisfogel DR, Kindt TJ. Identification and characterization of rabbit-mouse hybridomas secreting rabbit immunoglobulin chains. Proc Natl Acad Sci USA 1980; 77 2899-2903

126 Dreher KL, Sogn JA, Gates FT 3rd, Kuo MC, Kindt TJ. Allotype-defined mRNA for rabbit immunoglobulin $\mathrm{H}$ and $\mathrm{L}$ chains isolated from rabbitmouse hybridomas. J Immunol 1983; 130: 442-448.

127 Verbanac KM, Gross UM, Rebellato LM, Thomas JM. Production of stable rabbit-mouse heterohybridomas: characterization of a rabbit monoclonal antibody recognizing a $180 \mathrm{kDa}$ human lymphocyte membrane antigen. Hybridoma 1993; 12: 285-295.

128 Spieker-Polet H, Sethupathi P, Yam PC, Knight KL. Rabbit monoclonal antibodies: generating a fusion partner to produce rabbit-rabbit hybridomas. Proc Natl Acad Sci USA 1995; 92: 9348-9352.

129 Yam PC, Knight KL. Generation of rabbit monoclonal antibodies. Methods Mol Biol 2014; 1131: 71-79.
130 Liguori MJ, Hoff-Velk JA, Ostrow DH. Recombinant human interleukin-6 enhances the immunoglobulin secretion of a rabbit-rabbit hybridoma. Hybridoma 2001; 20: 189-198.

131 Yu J, Kane S, Wu J, Benedettini E, Li D, Reeves C et al. Mutation-specific antibodies for the detection of EGFR mutations in non-small-cell lung cancer. Clin Cancer Res 2009; 15: 3023-3028.

132 Cameron A, Giacomozzi B, Joyce J, Gray A, Graham D, Ousson S et al. Generation and characterization of a rabbit monoclonal antibody sitespecific for tau O-GlcNAcylated at serine 400. FEBS Lett 2013; 587: 3722-3728.

133 Ghosh P, Sahoo R, Vaidya A, Cantel S, Kavishwar A, Goldfine A et al. A specific and sensitive assay for blood levels of glycated CD59: a novel biomarker for diabetes. Am J Hematol 2013; 88: 670-676.

134 Pan R, Chen Y, Vaine M, Hu G, Wang S, Lu S et al. Structural analysis of a novel rabbit monoclonal antibody R53 targeting an epitope in HIV-1 gp120 C4 region critical for receptor and co-receptor binding. Emerg Microbes Infect 2015; 4: e44.

135 Qin Y, Banerjee S, Agrawal A, Shi H, Banasik M, Lin F et al. Characterization of a large panel of rabbit monoclonal antibodies against HIV-1 gp120 and isolation of novel neutralizing antibodies against the V3 loop. PLOS ONE 2015; 10: e0128823.

136 Chen Y, Vaine M, Wallace A, Han D, Wan S, Seaman MS et al. A novel rabbit monoclonal antibody platform to dissect the diverse repertoire of antibody epitopes for HIV-1 Env immunogen design. J Virol 2013; 87: 10232-10243.

137 Smith GP. Filamentous fusion phage: novel expression vectors that display cloned antigens on the virion surface. Science 1985; 228: 1315-1317.

138 Clackson T, Hoogenboom HR, Griffiths AD, Winter G. Making antibody fragments using phage display libraries. Nature 1991; 352: 624-628.

139 Barbas CF 3rd, Kang AS, Lerner RA, Benkovic SJ. Assembly of combinatorial antibody libraries on phage surfaces: the gene III site. Proc Natl Acad Sci USA 1991; 88: 7978-7982.

140 Winter G, Griffiths AD, Hawkins RE, Hoogenboom HR. Making antibodies by phage display technology. Annu Rev Immunol 1994; 12: 433-455.

141 Rader C, Barbas CF 3rd. Phage display of combinatorial antibody libraries. Curr Opin Biotechnol 1997; 8: 503-508.

142 Rader C. Antibody libraries in drug and target discovery. Drug Discov Today 2001; 6: 36-43.

143 Ridder R, Schmitz R, Legay F, Gram H. Generation of rabbit monoclonal antibody fragments from a combinatorial phage display library and their production in the yeast Pichia pastoris. Biotechnology 1995; 13: 255-260.

144 Chi XS, Landt Y, Crimmins DL, Dieckgraefe BK, Ladenson JH. Isolation and characterization of rabbit single chain antibodies to human Reg lalpha protein. J Immunol Methods 2002; 266: 197-207.

$145 \mathrm{Li} \mathrm{Y}$, Collins MS, Whitelam GC, Alexander DJ. Rapid pathotyping of Newcastle disease virus using a single-chain Fv displayed on phage against the C-terminal end of the F2 polypeptide. Arch Virol 2002; 147: 2025-2037.

146 Corte-Real S, Collins C, Aires Da Silva F, Simas JP, Barbas CF 3rd, Chang $Y$ et al. Intrabodies targeting the Kaposi sarcoma-associated herpesvirus latency antigen inhibit viral persistence in lymphoma cells. Blood 2005; 106: 3797-3802.

147 Nelson JD, Kinkead H, Brunel FM, Leaman D, Jensen R, Louis JM et al. Antibody elicited against the gp41 N-heptad repeat (NHR) coiled-coil can neutralize HIV-1 with modest potency but non-neutralizing antibodies also bind to NHR mimetics. Virology 2008; 377: 170-183.

148 Moon SA, Ki MK, Lee S, Hong ML, Kim M, Kim S et al. Antibodies against non-immunizing antigens derived from a large immune scFv library. Mol Cells 2011; 31: 509-513.

$149 \mathrm{Ma} \mathrm{H}$, Meng J, Wang J, Hearty S, Dolly JO, O'kennedy R. Targeted delivery of a SNARE protease to sensory neurons using a single chain antibody (scFv) against the extracellular domain of P2X(3) inhibits the release of a pain mediator. Biochem J 2014; 462: 247-256.

150 Gough KC, Maddison BC, Shikotra A, Moiseeva EP, Yang W, Jarvis S et al. Evidence for a novel Kit adhesion domain mediating human mast cell adhesion to structural airway cells. Respir Res 2015; 16: 86.

151 Da Silva FA, Li M, Rato S, Maia S, Malho R, Warren K et al. Recombinant rabbit single-chain antibodies bind to the catalytic and C-terminal domains of HIV-1 integrase protein and strongly inhibit HIV-1 replication. Biotechnol Appl Biochem 2012; 59: 353-366.

152 Lang IM, Barbas CF 3rd, Schleef RR. Recombinant rabbit Fab with binding activity to type-1 plasminogen activator inhibitor derived from a phage-display library against human alpha-granules. Gene 1996; 172: 295-298. 
153 Foti M, Granucci F, Ricciardi-Castagnoli P, Spreafico A, Ackermann M, Suter M. Rabbit monoclonal Fab derived from a phage display library. J Immunol Methods 1998; 213: 201-212.

154 Rader C. Generation and selection of rabbit antibody libraries by phage display. Methods Mol Biol 2009; 525: 101-128xiv.

155 Rader C, Ritter G, Nathan S, Elia M, Gout I, Jungbluth AA et al. The rabbit antibody repertoire as a novel source for the generation of therapeutic human antibodies. J Biol Chem 2000; 275: 13668-13676.

156 Popkov M, Rader C, Barbas CF 3rd. Isolation of human prostate cancer cell reactive antibodies using phage display technology. J Immunol Methods 2004; 291: 137-151.

157 Lee S, Yoon IH, Yoon A, Cook-Mills JM, Park CG, Chung J. An antibody to the sixth Ig-like domain of VCAM-1 inhibits leukocyte transendothelial migration without affecting adhesion. J Immunol 2012; 189: 4592-4601.

158 Cho AY, Shin KJ, Chung J, Oh S. A sensitive enzyme immunoassay for amygdalin in food extracts using a recombinant antibody. J Food Prot 2008; 71: 2048-2052.

159 Lee MS, Lee JC, Choi CY, Chung J. Production and characterization of monoclonal antibody to botulinum neurotoxin type $\mathrm{B}$ light chain by phage display. Hybridoma 2008; 27: 18-24.

160 Goncalves J, Silva F, Freitas-Vieira A, Santa-Marta M, Malho R, Yang X et al. Functional neutralization of HIV-1 Vif protein by intracellular immunization inhibits reverse transcription and viral replication. J Biol Chem 2002; 277: 32036-32045.

161 Hofer T, Tangkeangsirisin W, Kennedy MG, Mage RG, Raiker SJ, Venkatesh $\mathrm{K}$ et al. Chimeric rabbit/human Fab and IgG specific for members of the Nogo-66 receptor family selected for species crossreactivity with an improved phage display vector. J Immunol Methods 2007; 318: 75-87.

162 Zhuang X, Stahl SJ, Watts NR, Dimattia MA, Steven AC, Wingfield PT. A cell-penetrating antibody fragment against HIV-1 Rev has high antiviral activity: characterization of the paratope. J Biol Chem 2014; 289: 20222-20233.

163 Holliger P, Hudson PJ. Engineered antibody fragments and the rise of single domains. Nat Biotechnol 2005; 23: 1126-1136.

164 Hudson PJ, Kortt AA. High avidity scFv multimers; diabodies and triabodies. J Immunol Methods 1999; 231: 177-189.

165 Jendreyko N, Popkov M, Beerli RR, Chung J, Mcgavern DB, Rader C et al. Intradiabodies, bispecific, tetravalent antibodies for the simultaneous functional knockout of two cell surface receptors. J Biol Chem 2003; 278: 47812-47819.

166 Jendreyko N, Popkov M, Rader C, Barbas CF 3rd. Phenotypic knockout of VEGF-R2 and Tie-2 with an intradiabody reduces tumor growth and angiogenesis in vivo. Proc Natl Acad Sci USA 2005; 102: 8293-8298.

167 Popkov M, Jendreyko N, Mcgavern DB, Rader C, Barbas CF 3rd. Targeting tumor angiogenesis with adenovirus-delivered anti-Tie-2 intrabody. Cancer Res 2005; 65: 972-981.

168 Suter M, Blaser K, Aeby P, Crameri R. Rabbit single domain antibodies specific to protein C expressed in prokaryotes. Immunol Lett 1992; 33: 53-59.

169 Aires Da Silva F, Santa-Marta M, Freitas-Vieira A, Mascarenhas P, Barahona I, Moniz-Pereira J et al. Camelized rabbit-derived VH singledomain intrabodies against Vif strongly neutralize HIV-1 infectivity. J Mol Biol 2004; 340: 525-542.

170 Cunha-Santos C, Figueira TN, Borrego P, Oliveira SS, Rocha C, Couto A et al. Development of synthetic light-chain antibodies as novel and potent HIV fusion inhibitors. AIDS 2016; 30: 1691-1701.

171 Yu X, Mcgraw PA, House FS, Crowe JE Jr. An optimized electrofusionbased protocol for generating virus-specific human monoclonal antibodies. J Immunol Methods 2008; 336: 142-151.

172 Seeber S, Ros F, Thorey I, Tiefenthaler G, Kaluza K, Lifke V et al. A robust high throughput platform to generate functional recombinant monoclonal antibodies using rabbit B cells from peripheral blood. PLOS ONE 2014; 9: e86184.

173 Ojima-Kato T, Hashimura D, Kojima T, Minabe S, Nakano H. In vitro generation of rabbit anti-Listeria monocytogenes monoclonal antibody using single cell based RT-PCR linked cell-free expression systems. J Immunol Methods 2015; 427: 58-65.

174 Babcook JS, Leslie KB, Olsen OA, Salmon RA, Schrader JW. A novel strategy for generating monoclonal antibodies from single, isolated lymphocytes producing antibodies of defined specificities. Proc Natl Acad Sci USA 1996; 93: 7843-7848.
175 Ozawa T, Piao X, Kobayashi E, Zhou Y, Sakurai H, Andoh T et al. A novel rabbit immunospot array assay on a chip allows for the rapid generation of rabbit monoclonal antibodies with high affinity. PLOS ONE 2012; 7: e52383.

176 Lightwood DJ, Carrington B, Henry AJ, Mcknight AJ, Crook K, Cromie K et al. Antibody generation through $B$ cell panning on antigen followed by in situ culture and direct RT-PCR on cells harvested en masse from antigen-positive wells. J Immunol Methods 2006; 316: 133-143.

177 Starkie DO, Compson JE, Rapecki S, Lightwood DJ. Generation of recombinant monoclonal antibodies from immunised mice and rabbits via flow cytometry and sorting of antigen-specific IgG+ memory B cells. PLOS ONE 2016; 11: e0152282.

178 Kivi G, Teesalu K, Parik J, Kontkar E, Ustav M Jr., Noodla L et al. Hybrifree: a robust and rapid method for the development of monoclonal antibodies from different host species. BMC Biotechnol 2016; 16: 2.

179 Clargo AM, Hudson AR, Ndlovu W, Wootton RJ, Cremin LA, O'dowd VL et al. The rapid generation of recombinant functional monoclonal antibodies from individual, antigen-specific bone marrow-derived plasma cells isolated using a novel fluorescence-based method. MAbs 2014; 6: 143-159.

180 Georgiou G, Ippolito GC, Beausang J, Busse CE, Wardemann H, Quake $\mathrm{SR}$. The promise and challenge of high-throughput sequencing of the antibody repertoire. Nat Biotechnol 2014; 32: 158-168.

181 Cheung WC, Beausoleil SA, Zhang X, Sato S, Schieferl SM, Wieler JS et al. A proteomics approach for the identification and cloning of monoclonal antibodies from serum. Nat Biotechnol 2012; 30: 447-452.

182 Hwang WY, Foote J. Immunogenicity of engineered antibodies. Methods 2005; 36: 3-10.

183 Chatenoud L, Jonker M, Villemain F, Goldstein G, Bach JF. The human immune response to the OKT3 monoclonal antibody is oligoclonal. Science 1986; 232: 1406-1408.

184 Grossbard ML, Press OW, Appelbaum FR, Bernstein ID, Nadler LM. Monoclonal antibody-based therapies of leukemia and lymphoma. Blood 1992; 80: 863-878.

185 Morrison SL, Johnson MJ, Herzenberg LA, Oi VT. Chimeric human antibody molecules: mouse antigen-binding domains with human constant region domains. Proc Natl Acad Sci USA 1984; 81: $6851-6855$.

186 Jones PT, Dear PH, Foote J, Neuberger MS, Winter G. Replacing the complementarity-determining regions in a human antibody with those from a mouse. Nature 1986; 321: 522-525.

187 Zhang YF, Phung Y, Gao W, Kawa S, Hassan R, Pastan I et al. New high affinity monoclonal antibodies recognize non-overlapping epitopes on mesothelin for monitoring and treating mesothelioma. Sci Rep 2015; 5: 9928.

188 Steinberger P, Sutton JK, Rader C, Elia M, Barbas CF 3rd. Generation and characterization of a recombinant human CCR5-specific antibody. A phage display approach for rabbit antibody humanization. J Biol Chem 2000; 275: 36073-36078.

189 Waldmeier L, Hellmann I, Gutknecht CK, Wolter FI, Cook SC, Reddy ST et al. Transpo-mAb display: transposition-mediated $B$ cell display and functional screening of full-length IgG antibody libraries. MAbs 2016; 8: 726-740.

190 Rader C, Cheresh DA, Barbas CF 3rd. A phage display approach for rapid antibody humanization: designed combinatorial V gene libraries. Proc Natl Acad Sci USA 1998; 95: 8910-8915.

191 Weiner LM, Dhodapkar MV, Ferrone S. Monoclonal antibodies for cancer immunotherapy. Lancet 2009; 373: 1033-1040.

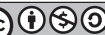

This work is licensed under a Creative Commons Attribution-NonCommercial-ShareAlike 4.0 International License. The images or other third party material in this article are included in the article's Creative Commons license, unless indicated otherwise in the credit line; if the material is not included under the Creative Commons license, users will need to obtain permission from the license holder to reproduce the material. To view a copy of this license, visit http://creativecommons.org/licenses/by-nc-sa/4.0/ 